\title{
The rise to dominance of lanternfishes (Teleostei: Myctophidae) in the oceanic ecosystems: a paleontological perspective
}

\author{
Werner Schwarzhans* (D) and Giorgio Carnevale (D)
}

\begin{abstract}
Lanternfishes currently represent one of the dominant groups of mesopelagic fishes in terms of abundance, biomass, and diversity. Their otolith record dominates pelagic sediments below $200 \mathrm{~m}$ in dredges, especially during the entire Neogene. Here we provide an analysis of their diversity and rise to dominance primarily based on their otolith record. The earliest unambiguous fossil myctophids are known based on otoliths from the late Paleocene and early Eocene. During their early evolutionary history, myctophids were likely not adapted to a high oceanic lifestyle but occurred over shelf and upper-slope regions, where they were locally abundant during the middle Eocene. A distinct upscaling in otolith size is observed in the early Oligocene, which also marks their earliest occurrence in bathyal sediments. We interpret this transition to be related to the change from a halothermal deep-ocean circulation to a thermohaline regime and the associated cooling of the deep ocean and rearrangement of nutrient and silica supply. The early Oligocene myctophid size acme shows a remarkable congruence with diatom abundance, the main food resource for the zooplankton and thus for myctophids and whales. The warmer late Oligocene to early middle Miocene period was characterized by an increase in disparity of myctophids but with a reduction in their otolith sizes. A second and persisting secular pulse in myctophid diversity (particularly within the genus Diaphus) and increase in size begins with the "biogenic bloom" in the late Miocene, paralleled with diatom abundance and mysticete gigantism.
\end{abstract}

Werner Schwarzhans. Natural History Museum of Denmark, Zoological Museum, Universitetsparken 15, DK-2100 Copenhagen, Denmark. E-mail: wwschwarz@aol.com

Giorgio Carnevale. Dipartimento di Scienze della Terra, Università degli Studi di Torino, Via Valperga Caluso 35 10125 Torino, Italy. E-mail: giorgio.carnevale@unito.it

Accepted: 8 January 2021

${ }^{*}$ Corresponding author.

\section{Introduction}

Lanternfishes (Myctophidae) are one of the dominant group of fishes in the mesopelagic zone of the oceans, together with the bristlemouths (Gonostomatidae) of the genus Cyclothone (Gjøsaeter and Kawaguchi 1980; Lam and Pauly 2005; Catul et al. 2011; Kaardtvedt et al. 2012; Irigoien et al. 2014). Due to their abundance, myctophids constitute a major part of the oceanic biomass and to a large extent are responsible for the deep scattering sonar layers in the oceans (Gjøsaeter 1984; Catul et al. 2011; Kaardtvedt et al. 2012; Irigoien et al. 2014). For instance, according to Hulley (1981), about 46\% to $87 \%$ of mesopelagic fishes caught in the eastern Atlantic are lanternfishes, although these percentages are dependent on the gear type used. Myctophids exhibit a very high degree of speciation compared with most other mesopelagic fishes, the mechanisms of which are still incompletely understood (Freer 2018). The order Myctophiformes contain two extant families, the Neoscopelidae, with 3 genera containing 6 extant species, and the Myctophidae, with 31 genera and 248 extant species currently considered valid (Froese and Pauly 2020), the latter arranged in five subfamilies (Gymnoscopelinae, Notolychninae, Lampanyctinae, Diaphinae, and Myctophinae) according to Martin et al. (2018). The genus Diaphus is the most speciose within the family, with 77 extant valid species (Froese and Pauly 2020), and is also the richest in the fossil record (see "Results" section). Many myctophid species live high oceanic lifestyles (sensu Hulley 1981) and are widely distributed in the world oceans, often cosmopolitan, with their distribution patterns primarily controlled by water temperature, food availability, and currents. However, a number of species are

(C) The Author(s), 2021. Published by Cambridge University Press on behalf of The Paleontological Society. This is an Open Access article, distributed under the terms of the Creative Commons Attribution licence (http://creativecommons.org/ licenses/by/4.0/), which permits unrestricted re-use, distribution, and reproduction in any medium, provided the original work is properly cited. 
restricted to certain oceanic environments or basins or exhibit a pseudoceanic lifestyle (sensu Hulley and Lutjeharms 1989; and e.g., Hulley 1992; Freer 2018). The life cycle of myctophids is relatively short; they reach maturity 1 to 2 years after hatching and rarely surpass 5 years in total (Catul et al. 2011). Many are adapted to occupy the oxygen minimum zones during the day (Douglas et al. 1976) and undertake diel vertical migration to the ocean surface layers at night (e.g., Marshall 1979). They occupy a midtrophic level, relying mainly on zooplankton, mostly crustaceans such as copepods, amphipods, and euphasiids (e.g., Tanaka et al. 2007). Although the diel vertical migration by zooplankton and myctophids is driven by escaping visually hunting predators, they can fall prey to predators along their migration route (Robison et al. 2020). Thus, they represent a major source of food in the oceanic trophic web for a vast array of predators (e.g., large fishes, squids, sea birds, beaked whales, dolphins, balaenopterid whales) (e.g., Robison et al. 2020). The excreta produced by their predators are regarded as the prime source for sedimentary accumulation of their otoliths (Nolf 1985). A study of subRecent otoliths obtained from sediments dredged along transects from 30 to $3500 \mathrm{~m}$ water depth in the Gulf of Guinea and off the Azores has revealed a dominance of myctophid otoliths below $200 \mathrm{~m}$ in the range of $75 \%$ to $95 \%$ of all the specimens collected (Schwarzhans 2013a; Supplementary Material 3). This observation is consistent with the abundance and spatial distribution of myctophid otoliths in the otolith assemblages of Neogene pelagic sediments.

The purpose of our study is to unravel the evolutionary history of myctophids primarily based on otoliths and to evaluate how their rise to dominance in the world oceans was achieved. We focus on the genus Diaphus, because it is the earliest extant myctophid genus recognized in the fossil record, the most common one, and the most speciose. We compare the evolution and increase in abundance of myctophids as revealed by their otolith record, with the evolution and abundance of other marine oceanic groups from lower (using diatoms as proxy) to higher trophic levels (using mysticete cetaceans as proxy). We evaluate potential interactions between these biotic groups and possible reactions to external drivers, particularly major changes in the oceanic sphere over time. The combination of the comparison of the paleontological records and the major oceanographic events are used to identify the putative drivers for the exceptional rise to prominence of the lanternfishes during the last 30 to $35 \mathrm{Myr}$.

\section{Material and Methods}

Information about otolith sizes (OL) and corresponding body sizes (SL) derive from Rivaton and Bourret (1999), Schwarzhans (2013b), and from the collection of W.S., represented by 204 specimens measured for both SL and OL and listed in Supplementary Material 1. The analysis of fossil myctophids is primarily based on the rich otolith records from recent literature (e.g., Nolf 2013; Schwarzhans 2013b,c, 2019; Schwarzhans and Aguilera 2013; Schwarzhans and Ohe 2019) and ongoing research by W.S., that is, of fossils from Japan and Chile, and is summarized and explained in Supplementary Materials 2 and 3. A total of 63 productive localities have been examined, recording the time interval from Ypresian to Calabrian (listed in Supplementary Material 3). Comparative data for other fossil groups and paleoceanographic data have been derived from the literature.

The otolith terminology follows the morphological nomenclature established by Koken (1884) and Weiler (1942) with amendments by Schwarzhans (1978). For a detailed description of otoliths of the genus Diaphus, see Schwarzhans (2013b) (Fig. 1).

\section{Results}

Recognition of Myctophid Otoliths.-Myctophid otoliths are distinguished from those of the sister-family Neoscopelidae by two main characters (Fig. 1):

1. Ostium longer than cauda (length of ostial colliculum to caudal colliculum 1.0-3.5) versus cauda longer than ostium (length of ostial colliculum to caudal colliculum 0.75-1.0).

2. Presence of a distinct caudal pseudocolliculum (a collicular crest ventral of the caudal colliculum; see Schwarzhans 1978). 

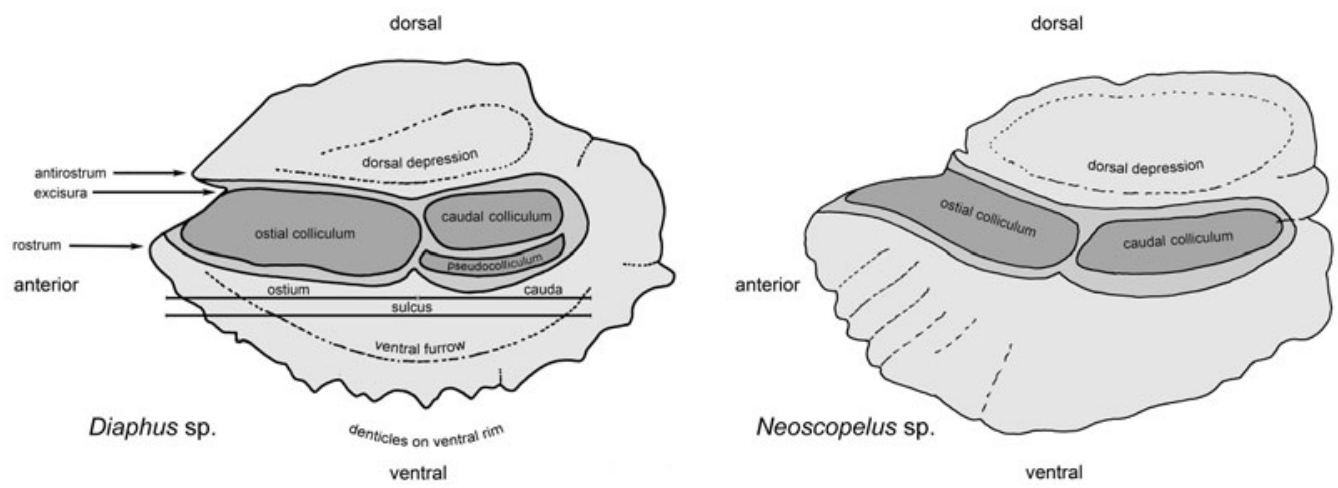

FIGURE 1. Morphology and terminology of myctophid (Diaphus, left side) and neoscopelid otoliths (Neoscopelus, right side).

Both features are considered apomorphic for the Myctophidae (Schwarzhans 2012). The caudal pseudocolliculum is almost exclusively known from myctophids and is considered to represent a clear synapomorphy of the family. Popper (1977) observed a group of large, square cells just ventral to the posterior ventral margin of the macula of the saccular otolith. This linear stretch of cells presumably correlates with the caudal pseudocolliculum. Another noticeable feature in many myctophid otoliths is the denticles along the ventral rim (in the genera Diaphus, Lampanyctodes, Lobianchia, and some species of Benthosema and Lampadena), which can vary interspecifically in number, position, and robustness.

Paleontological Record of Myctophids.- - Highly diagnostic morphological traits enable a reliable recognition of fossil myctophid otoliths as such, even when eroded or juveniles. The earliest known unambiguous record is Eokrefftia prediaphus Schwarzhans, 1985 from the late Paleocene of South Australia (Fig. 2), which is also the first myctophiform otolith with a clearly developed caudal pseudocolliculum. However, there are records of a supposed neoscopelid from the middle Paleocene of western Greenland, and of putative stem myctophiforms from the Maastrichtian and the Paleocene (Bavariscopelus and Danoscopelus; Schwarzhans 2010a, 2012), all of which do not have a pseudocolliculum or only a rather incipient indication thereof. The fossil skeletal record also has some problematic Late Cretaceous myctophiforms, for example, Sardinius,
Sardinioides, and Tachynectes (Goody 1969; Patterson 1993; Dietze 2009). Prokofiev (2006) placed these and some other related genera in the order Nematonotiformes, which he considered to represent the closest relative of the Myctophiformes.

Myctophid otoliths occur regularly in Eocene deposits, as well as in the Oligocene, although with a limited diversity and abundance (here and later considered as the percentage of myctophid specimens within the respective otolith assemblage; see Supplementary Material 3) compared with the Neogene. The first rich assemblage exhibiting a considerable abundance of myctophid otoliths has been described from outer shelf deposits in SW France (Lin et al. 2016). The Eocene and Oligocene myctophid otoliths have been variously assigned to the genus Diaphus and to the fossil genera Eomyctophum and Oligophus, which have been linked to skeletal remains with otoliths in situ (Schwarzhans 1985; Prokofiev 2006; Přikryl et al. 2017). Articulated skeletons of Eomyctophum were originally placed in Diaphus but have been subsequently recognized as pertaining to a lampanyctine (sensu Paxton 1972) genus (Prokofiev 2006). Prokofiev (2006) therefore established the extinct subfamily Eomyctophinae to include Eomyctophum as a genus characterized by a mosaic of lampanyctine and myctophine features. The otolith morphology of Eomyctophum appears to be plesiomorphic, as indicated by a relatively faint caudal pseudocolliculum and regularly curved rims usually without denticles or prominent 


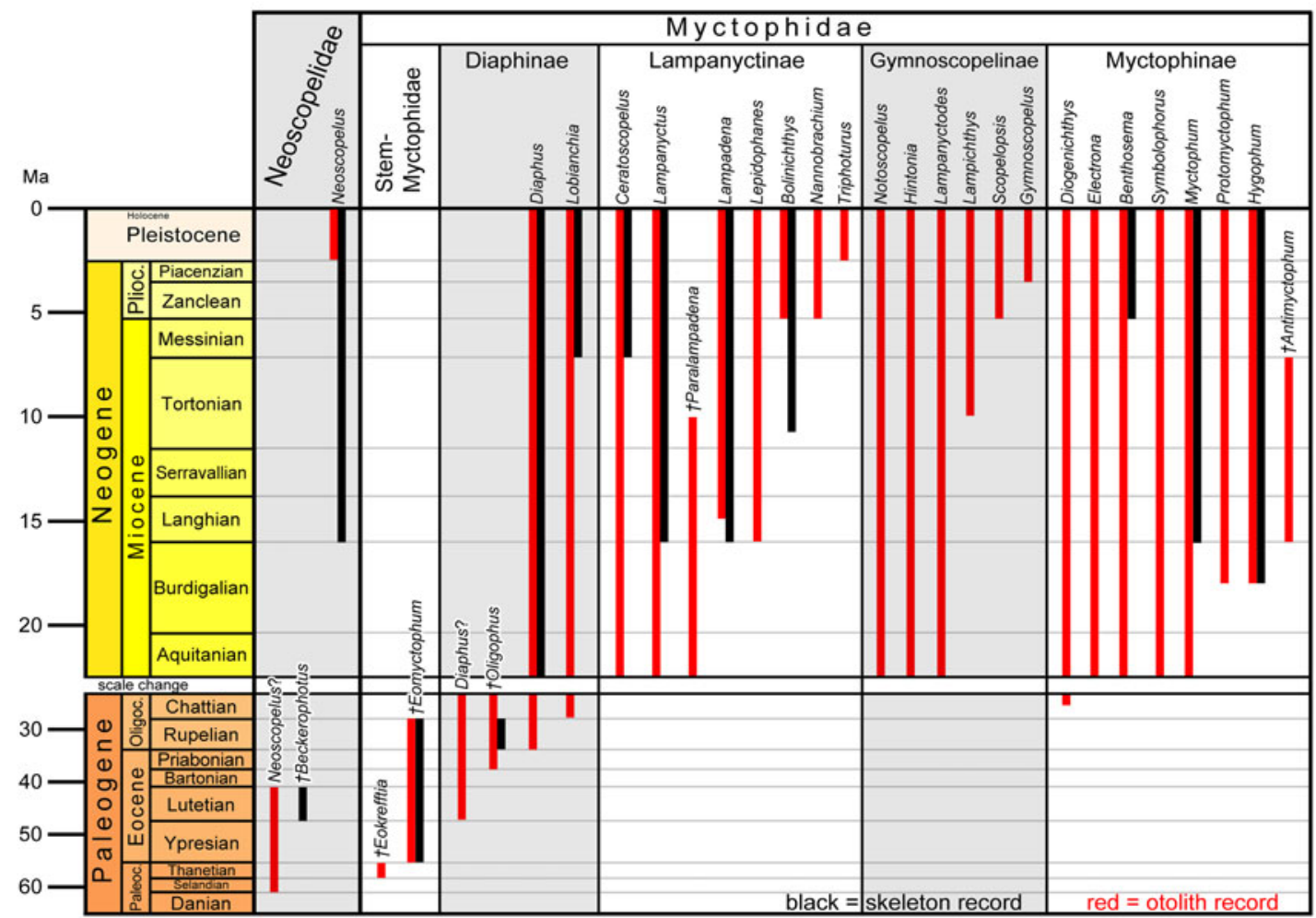

FIGURE 2. Myctophid and neoscopelid range chart/myctophid diversity. Ranges may include ghost intervals, which, however, are negligible in the case of fossil otolith records; $\uparrow$ denotes extinct genera. (In color online.)

angles, thereby supporting the recognition of a stem-myctophid subfamily that includes Eomyctophum and the otolith-based genus Eokrefftia (Fig. 2). The allocation of isolated otoliths to Eomyctophum, Oligophus, or to putative early Diaphus forms has been somewhat controversial in the past (Nolf 1988; Lin et al. 2016; Schwarzhans 2019). The main characters useful for distinction are the rather regularly rounded dorsal rim and crenulated ventral margin without denticles or with only a few or incipient ones in Eomyctophum, while the presence of distinct denticles along the ventral margin is one of the most reliable diagnostic characters of Diaphus and Oligophus (see Přikryl et al. 2017). Certain Eocene otoliths traditionally referred to Diaphus exhibit a somewhat intermediate morphology between Diaphus and Oligophus. In any case, the Eocene to Oligocene putative otolith-based Diaphus species are only tentatively assigned to this genus (Diaphus? in Fig. 2) and cannot be related to any of the extant species groups of Diaphus. We consider these extinct species as representing a "stem Diaphus" group. The articulated skeletons currently referred to the genus Oligophus were originally considered as representatives of Diaphus (Kalabis 1948) until they were reassigned to this newly established fossil genus by Gregorová (2004). In this context, it is interesting to note that otoliths in situ revealed that the otolithbased Diaphus longirostris (Brzobohatý, 1967) represents a junior synonym of the skeletonbased Oligophus moravicus (Pauca, 1931) (see Přikryl et al. 2017).

Oligocene to Neogene otolith assemblages document a gradual increase of myctophid abundance and diversity. All major extant subfamilies, as well as many of the extant genera, are recognized for the first time from the 5 Myr interval ranging from the late Oligocene to the early Miocene (Fig. 2). New Zealand is a key area that harbors many of the early-stage crown Myctophidae (Schwarzhans 2019), but 
other areas such as Europe (Steurbaut 1979; Nolf and Brzobohatý 2002), West Africa (Schwarzhans 2013c), Japan (Schwarzhans and Ohe 2019; unpublished data), and tropical America (Schwarzhans and Aguilera 2013) also contain rich Miocene myctophid assemblages. After this initial radiation, the level of myctophid disparity has remained rather constant until today, although significant increases in the number of species and size occurred within the genus Diaphus (see below).

The skeletal record of myctophids is rather rich but certainly not to the same extent as the otolith one. However, the overall trend in diversity and abundance, although patchy and less continuous, is similar to that recognized on the basis of otoliths. Articulated skeletal remains certainly belonging to the families Neoscopelidae and Myctophidae are known since the Eocene (Prokofiev 2006; Zorzin et al. 2011), although undescribed putative lanternfishes have been reported from the Maastrichtian of Hokkaido, Japan (Uyeno and Matsui 1993). A moderate increase in abundance and diversity can be recognized since the early Oligocene, when myctophids became rather common in the mesopelagic fish assemblages of Europe (see Prrikryl et al. 2017). During the Miocene, the representatives of the extant genera appeared in the record, and especially since the Langhian, lanternfish remains became the dominant group in terms of abundance in the pelagic fish assemblages worldwide (e.g., Arambourg 1927; David 1943; Sato 1962, 1965; Bedini et al. 1986; Yabumoto and Uyeno 1994; Carnevale 2007; Denton 2013), a trend that persisted in the Pliocene and Quaternary. Overall, the timing of evolutionary events in myctophids is consistent with the timing of events interpreted from the molecular estimations proposed by Denton (2018), who hypothesized an early Paleogene divergence of the Myctophidae followed by the appearance of the main clades around the Eocene-Oligocene transition (EOT). Denton (2018) showed a density plot of core rate shifts peaking during the early Miocene (Burdigalian) and accelerating again during the late Miocene and Pliocene (Denton 2018: fig. 4).

Fossil Otolith Record of Diaphus._-Diaphus is by far the most speciose genus within the family Myctophidae, with 77 recognized extant species (80 species including the related genera Lobianchia and Idiolychnus, which form the Diaphinae [sensu Martin et al. 2018]). About 74 otolith-based fossil species are currently known, distributed over a time interval from the Eocene to the Pliocene, and include the putative "stem-Diaphus" species as well as the species currently being described by one of us (W.S.) from Japan and Chile (Supplementary Material 2). About 30 species are known from the late Pliocene/early Pleistocene (Fig. 3), representing the richest time interval in the fossil record. The discrepancy between 77 Recent species and 30 in the late Pliocene/early Pleistocene time interval may serve as an indication of the degree of incompleteness of the fossil record, which we believe is mainly due to the lack of sufficient superregional sampling and partly to the fact that not all the species can be unambiguously distinguished by means of isolated otoliths (Schwarzhans 2013b). The time intervals from the middle Miocene to the early Pliocene contain 15 to 20 species per segment, the Burdigalian between 10 and 13 species, and all earlier time intervals 6 or fewer species each. Thus, the increase in species numbers through time reflects an asymptotic trend over an interval of about 20 Myr. However, the real magnitude of the past diversity will not be completely deciphered until many more localities are screened for otoliths both on a greater spatial scale and in underrepresented time intervals, especially those ranging from the Rupelian to the Aquitanian (Fig. 3). Nevertheless, we interpret this clear and unbroken trend of increase in species richness as a genuine indication of an ongoing accelerated speciation within the genus Diaphus, which is congruent with the results derived from molecular time trees (Denton 2018).

The majority of Neogene Diaphus otoliths can be linked to extant species groups. The Diaphus theta species group, characterized by the presence of an So (suborbital) head photophore, is probably also the best-defined group by means of otoliths (see Schwarzhans 2013b; Tuset et al. 2018). Its earliest record dates back to the early Miocene (Aquitanian) of Germany, being represented by the species Diaphus simplex Schwarzhans 2010 (cited in the present paper as Schwarzhans 2010b). 


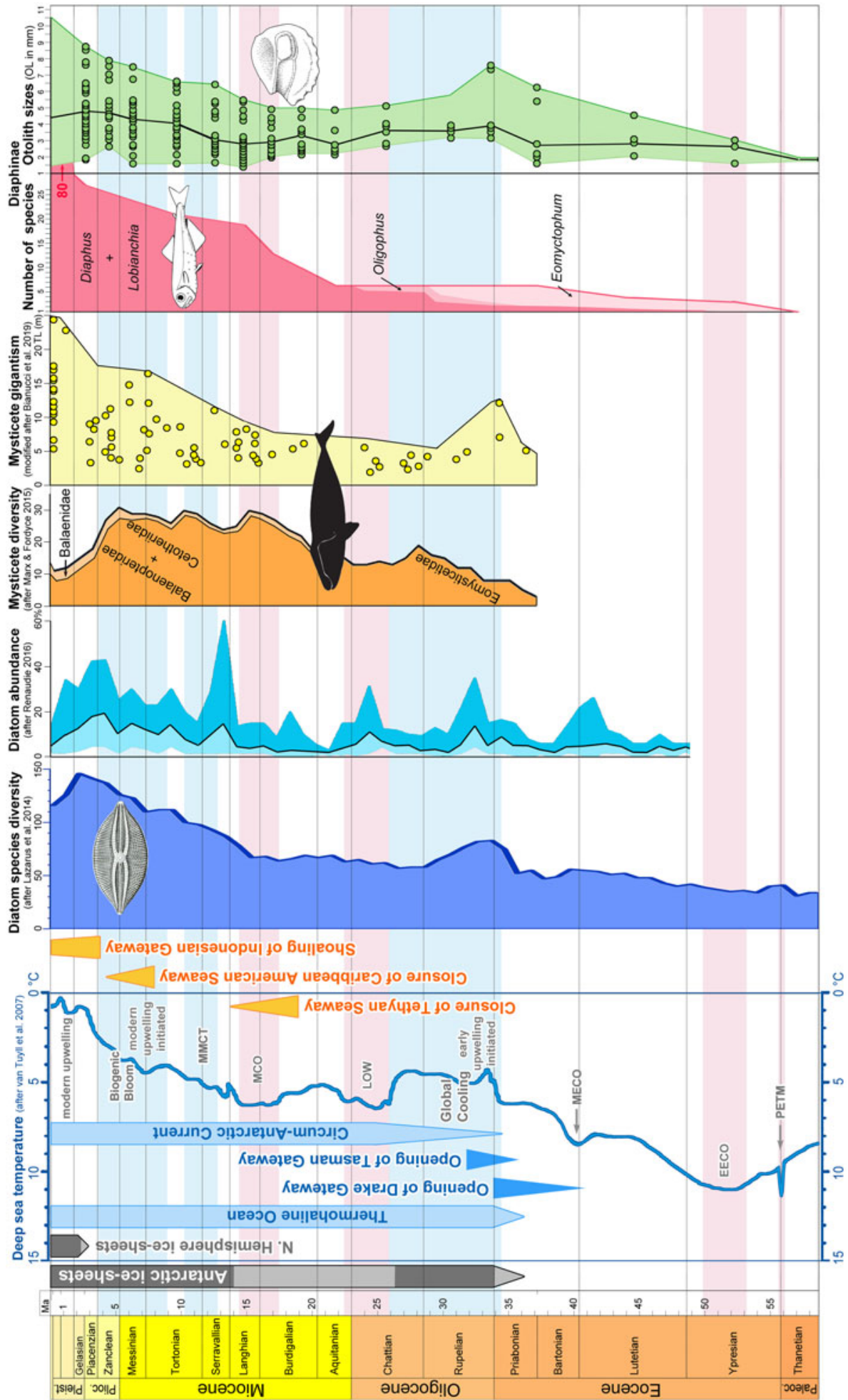

FIGURE 3. Proxies of global geodynamic, oceanographic, and selected biogenic events. On the left side, a compilation of exogenic events used in the summary in Schwarzhans (2019), including a corrected deep-sea temperature curve after van Tuyll et al. (2007). Blue shaded intervals mark global cooling phases, and red shaded intervals indicate global warming 
Body and Otolith Sizes in Diaphus Species.The extant species of Diaphus attain maximum sizes between $35 \mathrm{~mm}$ standard length (SL) in the dwarfed D. anderseni and $200 \mathrm{~mm}$ SL in the largest species, D. adenomus Gilbert, 1905; however, the average maximum size per species is likely less than $100 \mathrm{~mm}$ SL. A correlation of SL with otolith length (OL) of 204 specimens of various species of Diaphus based on Schwarzhans (2013b) and Rivaton and Bourret (1999) shows a clear trend $\left(y=0.59 X^{2}+13.45 x\right.$ $\left.+2.79 ; R^{2}=0.914\right)$ with only very few outliers (Supplementary Fig. 1, Supplementary Material 1). This allows for the estimation of the relative size of the fossil specimens of this genus based on the size of their isolated otoliths. The average $100 \mathrm{~mm}$ SL corresponds approximately to an average OL of about $5 \mathrm{~mm}$ and the average $130 \mathrm{~mm}$ SL threshold to an average OL of about $7 \mathrm{~mm}$. "Supersized species" are here defined as species growing to sizes larger than $130 \mathrm{~mm}$ SL and with otoliths measuring more than $7 \mathrm{~mm}$ in length, all of them pseudoceanic: Diaphus adenomus, D. gigas, D. mascarensis, D. watasei, D. whitleyi, plus two species currently being described by Hiromitsu Endo (Supplementary Fig. 1). Of these, at least three species, D. adenomus, D. mascarenensis, and D. watasei, are known to live close to the sea bottom (benthopelagic) and do not undertake diel vertical migrations, at least not after having reached a certain size (Gong et al. 2018; Meera et al. 2018; Froese and Pauly 2020). Other Diaphus species with a similar behavior appear to be D. dumerilii (shelf-slope-living populations), D. chrysorhynchus, D. suborbitalis, D. taaningi (P. Alexander Hulley personal communication August 2020), and D. coeruleus (Meera et al. 2018). Diaphus gigas is the only known "supersized" species of Diaphus performing diel vertical migrations (Watanabe et al. 1999). We consider the cessation of vertical migration behavior to be a secondary achievement, although its cause and evolution remain elusive. Diaphus coeruleus and D. watasei are known to feed mainly on deep-sea squids, larger crustaceans, and smaller fish, often smaller lanternfishes (Gong et al. 2018; Meera et al. 2018). Stomach content investigations in D. effulgens, which also grows to sizes greater than $130 \mathrm{~mm} \mathrm{SL}$, have revealed a change from a diet based on ostracods and copepods as principal prey in small specimens to a diet relying on fishes in larger specimens (Rathnasuriya et al. 2018). The geographic distribution of the supersized pseudoceanic Diaphus species varies between the different species from restricted to a single ocean basin (e.g., D. mascarensis in the western Indian Ocean) to cosmopolitan but disjunctive (D. adenomus), where it is usually associated with upper-slope regions at depths ranging between 200 and $1000 \mathrm{~m}$. The disjunctive distribution pattern possibly reflects the availability of selected food sources and could be linked to oceanic areas favoring short trophic chains, which may occur in upwelling systems or offshore from areas of high silica input from the adjacent continent (see next chapter and Edwards et al. 2010).

\section{Synthesis and Discussion}

Evolution of Environmental Adaptation of Lanternfishes.-Early Paleogene pelagic sediments have rarely been explored for otolith research. Outer-shelf to upper-slope Paleocene sediments from Bavaria yielded fairly abundant stomiiform otoliths as the only reliable indicators of deepwater conditions (Schwarzhans 2012). The early myctophid otolith finds from the Eocene are relatively sparse in a variety of inner- to outer-shelf and upper-slope environmental settings (Fig. 4). For instance, Diaphus? marambionis was found in middle Eocene sediments of Seymour Island, Antarctica, in a very shallow,

phases. Diatom diversity after Lazarus et al. (2014) and abundance after Renaudie (2016); graphs stretched to match scale and colored. Mysticete diversity after Marx and Fordyce (2015) and Mysticete gigantism after Bianucci et al. (2019) with an update for latest Eocene from Marx et al. (2019); graphs stretched to match scale and colored; Mysticete gigantism envelope generated from plots. The number of Diaphus species and Diaphus otolith sizes is clustered for defined time intervals, as seen in the otolith size plot (one plot can be more than one species). Data used to calculate Diaphus otolith sizes and plots are provided in Supplementary Material 2. Abbreviations: EECO, early Eocene climate optimum; LOW, late Oligocene warming; MCO, Miocene climate optimum; MECO, middle Eocene climate optimum; MMCT, middle Miocene climate transition; PETM, Paleocene-Eocene thermal maximum; OL, otolith length. (In color online.) 

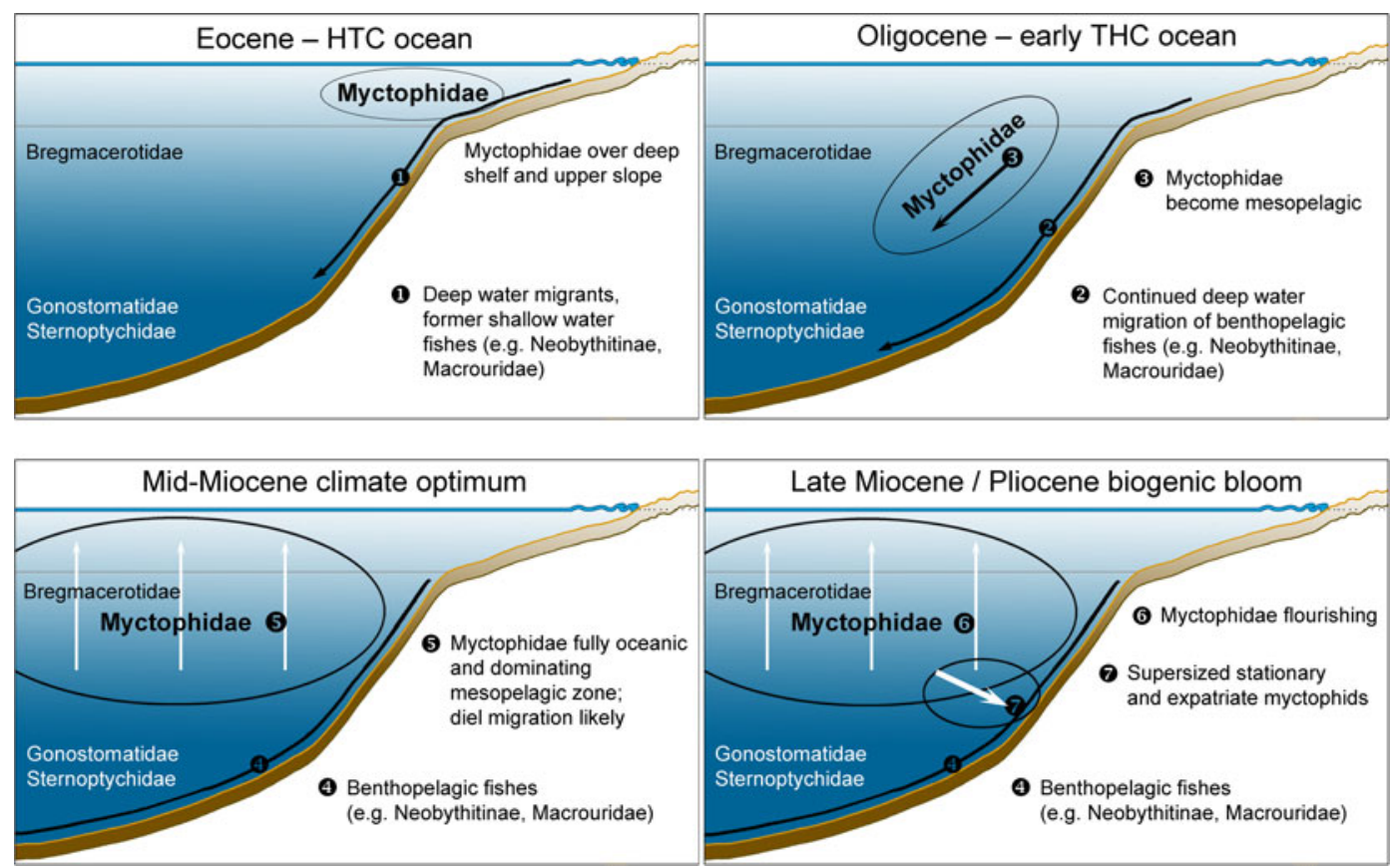

FIGURE 4. Aspects of the population of the deep-sea Myctophidae and selected other groups. Interpretation of bathymetric and oceanic habitat of selected teleost groups in the Eocene halothermal (HTC) ocean (upper left), Oligocene early thermohaline (THC) ocean (upper right), middle Miocene climate optimum (MCO) (lower left), and during the time of the biogenic bloom (lower right). Black arrows indicate presumed phases of down-slope or open-oceanic migrations. White arrows indicate presumed established diel vertical migration in myctophids.

nearshore environment, associated with abundant macrourid otoliths (Schwarzhans et al. 2017). In New Zealand, too, myctophid otoliths are relatively rare in inner- to outer-shelf settings during the Eocene, being absent in genuine offshore bathyal sediments (Schwarzhans 2019). Myctophids are, however, locally abundant in the middle Eocene of the Aquitaine Basin in SW France in outer-shelf to upper-slope environments (Nolf 1988; Lin et al. 2016) but mostly not exceeding $25 \%$ of the assemblage, except for certain locations in the late middle Eocene, where apparently they can reach up to $85 \%$ (Lin et al. 2016) (Fig. 4, Supplementary Material 3). These paleobiotopes are interpreted to have been located in a "deep neritic" environment (Lin et al. 2016). Recently, Schwarzhans (2019) described several assemblages from middle and upper Eocene sediments of New Zealand deposited at depths ranging from 200 to $700+$ $\mathrm{m}$. These assemblages provide a rare insight into Paleogene deep-sea fish faunas containing otoliths of the families Bregmacerotidae, Gonostomatidae, Sternoptychidae, Macrouridae, and
Ophidiidae, but no Myctophidae (except for a very few in the most shallow-water location studied). We interpret the occurrence of myctophids in SW France and their absence in New Zealand as an indication that these fishes lived over the deep-shelf and upper-slope environments in the middle and late Eocene but were not yet adapted to a mesopelagic habitat. Based on the limited data currently available, it seems that they first thrived over the continental break beginning in the middle Eocene before expanding into the mesopelagic zone. However, the transition from a deep-shelf continental to a mesopelagic habitat likely occurred gradually, and it is therefore possible that such an ecological transition took place during the middle to late Eocene. For instance, the Macrouridae and Ophidiidae in the bathyal late Eocene of New Zealand were represented by a single species each, while different taxa existed on the shelf, indicating the initiation of a migration into deep waters and a progressive depth segregation of involved species. These assemblages also included representatives of families that currently do 
not live off the shelf (Hemerocoetidae and Platycephalidae), apparently an indication of a failed attempt to invade the deep sea. We interpret these findings as an evidence of the fact that during the Eocene bregmacerotids already lived in the mesopelagic zone and stomiiforms in the bathypelagic zone, while myctophids stayed over the shelf and the upper slope. Certain groups of typical extant benthopelagic fishes like macrourids and ophidiids (Neobythitinae) started to migrate into the deep sea during that period (Lin et al. 2016; Schwarzhans 2019) (Fig. 4, upper left).

The picture changed drastically in the early Oligocene, as demonstrated by the unique otolith assemblages described by Nolf and Steurbaut $(1988,1990,2004)$ from Pizzocorno and Vigoponzo in Italy and corroborated by the articulated skeletal remains from the Czech Republic, North Caucasus, Poland, Romania, and Ukraine (e.g., Prrikryl et al. 2017 and literature cited therein). The Italian faunas exhibit a diverse and rich assemblage of myctophid, macrourid, and ophidiid (neobythitine) otoliths, suggesting that myctophids moved off the shelf into the oceanic realm and macrourids and neobythitines ventured further into the deep sea and diversified (Fig. 4, upper right). This is the earliest record where myctophids represent the majority of an otolith assemblage in a pelagic environment characterized by bathyal depths (Fig. 3, Supplementary Material 3). The basal part of the early Oligocene is also remarkable for the occurrence of some large-growing "supersized" Diaphus taxa (D. molossus and D. stafforaensis) (see Brzobohatý and Nolf 1995), with otoliths that reached sizes up to nearly $8 \mathrm{~mm}$ OL (Fig. 3, Supplementary Material 2).

During the late Oligocene and Neogene, lanternfishes apparently became a prominent mesopelagic fish family, and their otoliths started to dominate otolith assemblages in pelagic sediments (Nolf and Brzobohatý 2002; Schwarzhans 2019) (Supplementary Material 3). All the major myctophid groups and a large part of the extant genera are known based on fossil otoliths (Fig. 2), which document a diversification pattern that is consistent with the molecular estimations proposed by Denton (2018). Due to the abundance of myctophid otoliths in offshore pelagic sediments since the Oligocene, we postulate that they were adapted to their current lifestyle, which possibly included diel vertical migrations. However, some species persisted on the shelf, for instance, in the North Sea Basin (Schwarzhans 2010b) or tropical South America (Schwarzhans and Aguilera 2013). During the late Oligocene up to the mid-Miocene climate transition (MMCT), the majority of the otolith-based Diaphus species remained below the $5 \mathrm{~mm}$ OL threshold (about 80-110 mm SL) (Fig. 3, Fig. 4, lower left). During the late Miocene, Pliocene, and Quaternary, an increase in the number of species is observed as well as the gradual occurrence of some large-growing Diaphus species (Fig. 3). This can be interpreted as an indication of the appearance of possibly more stationary, benthopelagic species on the continental slope, in addition to a sustained diversification of myctophids in the mesopelagic zone (Fig. 4, lower right).

The Rise of Myctophids in the Oceanic Trophic Web and Its Paleoceanographic Context.-Extant myctophids feed primarily on planktonic crustaceans (copepods, euphasiids, and amphipods) in the epipelagic zone during their diel vertical migration (e.g., Tanaka et al. 2007). These planktonic crustaceans in turn feed mostly on phytoplankton, which nowadays consist mainly of diatoms and silicoflagellates (Sommer et al. 2002). Planktonic crustaceans are rather rare in the fossil record (Briggs et al. 1993; Rigby and Milsom 2000), so we have used diatom diversity and abundance as proxies for the primary productivity (Renaudie 2016) relevant for myctophids (Fig. 3). The presence and abundance of diatoms are primarily linked to the availability of silicon and phosphorus. These elements can be abundant in upwelling systems (Sommer et al. 2002) or can be consistently provided by terrestrial denudation and runoff from continents, with a considerable contribution from grasslands (Kidder and Gierlowski-Kordesch 2005; Beerling and Osborne 2006; Edwards et al. 2010; Strömberg 2011; Cermeño et al. 2015; Pellegrino et al. 2018). In the shortened food webs characteristic of upwelling systems and in other oceanic settings with a high silica budget, the planktonic crustaceans occupy the immediate basal trophic level compared with myctophids (Sommer et al. 2002), while in 
oligotrophic oceanic systems the food chain starts with picoplankton, resulting in a longer food chain (Sommer et al. 2002). The shortened food chain typical of upwelling systems may sustain an efficient transfer of organic carbon to apex predators (Ryther 1969), thereby generating favorable conditions for the thriving of large filter feeders, that is, whales (Berger 2007). Mysticete cetaceans are food competitors of lanternfishes for planktonic crustaceans, as well as their predators (Kawamura 1980). We have therefore used the rather well documented fossil record of mysticete cetaceans (Fordyce and Barnes 1994; Berger 2007; Marx and Uhen 2010; Marx et al. 2016, 2019; Bianucci et al. 2019) as a proxy for the evolutionary history of relevant competitors and predators of lanternfishes.

The rare myctophid otoliths from the late Paleocene to the middle Eocene are found in a variety of neritic settings (Schwarzhans 1985, 2019; Nolf 1988; Lin et al. 2016) and are small in size (Fig. 3, Supplementary Material 2 and 3), exhibiting a low degree of morphological diversity. Myctophid otoliths were locally abundant over outer-shelf settings since the late middle Eocene (Lin et al. 2016). The first major event that impacted lanternfish evolution appears to be the EOT. The EOT was characterized by a global cooling event and the termination of the foregoing greenhouse conditions apparently associated with a secular reduction of atmospheric $\mathrm{CO}_{2}$ (Zachos et al. 2008; Beerling and Royer 2011) and the onset of the Antarctic ice sheet (e.g., Lear et al. 2004). The EOT marked the transformation of the deep-ocean circulation from halothermal (HTC), primarily driven by density gradients linked to the salinity of the water masses, to thermohaline (THC), primarily driven by temperature gradients (McClain and Hardy 2010; Katz et al. 2011). The HTC circulation resulted from the formation of warm, saline, low-oxygen deep waters induced by stratification, whereas the THC circulation resulted from the formation of high-latitude cold and oxygenated deep waters (Katz et al. 2011; McClain and Hardy 2010; Norris et al. 2013). However, the exact sequence and timing of the events with respect to the different oceanic circulation patterns involved and their causes remain a matter of discussion (see, e.g., Katz et al. 2011; Goldner et al. 2014; Coxall et al. 2018). Between 36 and $33 \mathrm{Ma}$, a combination of geodynamic and paleoceanographic events led to a general restructuring of the global ocean system, including the isolation of Antarctica and formation of the (initial) Antarctic Circumpolar Current (Kennett 1977; Kennett and Exon 2004; Scher and Martin 2006; Barker et al. 2007; Strugnell et al. 2008; Katz et al. 2011; Houben et al. 2013), formation of the North Atlantic Deep Water Current induced by an increase in seawater density caused by polar cooling and following the submersion of the Arctic Ocean to North Atlantic swell for deep-water flow (Berger 2007; Katz et al. 2011; Borrelli et al. 2014; Coxall et al. 2018), demise of the Tethyan deep-water connection (Jovane et al. 2009; Steeman et al. 2009; Zhang et al. 2011), and denudation of adjacent uplifted terrains (Cermeño et al. 2015). The cooling and oxygenation of the deep oceanic masses induced migration of new taxa into the deep sea (Miller et al. 1992; Thomas 2007). Among fishes, these oceanographic changes resulted in an accelerated migration of benthopelagic fishes, for example, of the Macrouridae and Neobythitinae (Ophidiidae) (Nolf and Steurbaut 1988, 1990, 2004; Lin et al. 2016; Schwarzhans 2019), into the deep sea. Conversely, Sibert et al. (2020) did not recognize any state change in pelagic fish production and biodiversity during the EOT based on investigations of microfossil fish teeth from deep-sea drilling samples. However, due to the limited taxonomic resolution offered by ichthyoliths, it is not possible to identify the emergence and duration of fundamental changes of lifestyles, such as migration into the deep sea or the mesopelagic high ocean realms. The reorganization of the oceanic system and the formation of the THC led to the establishment of upwelling systems, particularly in the Southern Ocean (Berger 2007). This, in combination with an assumed locally elevated silica influx from the continents (e.g., Antarctica; see Cermeño et al. 2015), is thought to have resulted in a massive radiation of diatoms both in terms of diversity and abundance (Lazarus et al. 2014; Cermeño et al. 2015; Renaudie 2016; Lowery et al. 2020). The 
terminal Eocene is also the time of the first occurrence of mysticete whales (Fordyce and Marx 2018; Buono et al. 2019; Muizon et al. 2019), which, however, were not filter feeders. The early radiation of modern cetaceans has been interpreted as having been driven by this ocean restructuring (Fordyce 2003; Berger 2007; Steeman et al. 2009; Marx and Uhen 2010). As far as lanternfishes are concerned, Nolf and Steurbaut (1988, 1990, 2004) described the first exclusive bathyal otolith assemblage with a rich mesopelagic myctophid component from the basal Oligocene, a time during which the THC regime is thought to have been firmly established in the western Tethys (Coccioni and Galeotti 2003). Myctophids constituted about $30 \%$ to more than $50 \%$ of the otolith assemblage (calculated from Nolf and Steurbaut 2004; Fig. 3, Supplementary Material 3). Intriguingly, there is an apparent acme of diatom diversity and abundance during the terminal Eocene/ basal Oligocene associated with a short-term occurrence of gigantic mysticete predators (Marx et al. 2019) and certain supersized Diaphus species (Fig. 3, Supplementary Material 2). It is interesting to note that this late Eocene-early Oligocene pulse in diatom radiation and upscaling of certain whales and myctophids coincided with a putative increase in silica influx to the sea, particularly in the Southern Ocean (Cermeño et al. 2015). The Antarctic species Diaphus? marambionis was originally considered to be of early Eocene, Ypresian age (Schwarzhans et al. 2017), but the strata from which it was obtained has more recently been referred to the Bartonian, based on the stratigraphic scheme published by Buono et al. (2019). It was found at the same location and level as the earliest-recorded basking shark (Cetorhinidae; Cione and Reguero 1998; Welton 2013) and in a slightly older level than the abovementioned gigantic mysticete predator in Antarctica (Fig. 3). The size of the otoliths of Diaphus and Eomyctophum species shows a gradual increase from $1.6-3.0 \mathrm{~mm}$ OL in the early Eocene to 3.3-7.7 mm OL in the basal Oligocene.

Shortly after the basal Oligocene, the otolith sizes of the Diaphus species drop back into the range of $2.0-5.0 \mathrm{~mm}$ OL, a pattern that persisted throughout the late Oligocene to the early middle Miocene (Fig. 3, Supplementary
Material 2). In fact, their small size is so remarkable in samples that it can be regarded as a reliable stratigraphic feature for their distinction from the Late Miocene and Pliocene myctophid assemblages. Similarly, there are no more records of giant mysticetes in this time interval. Also, the abundance and diversity of diatoms seemingly dropped back to the level of a generally increasing background trend, except for a single short-lived abundance peak in the late Oligocene (Renaudie 2016). The abundance of myctophid otoliths reached high levels in pelagic environments during this time (Nolf and Brzobohatý 2002; Schwarzhans 2019; Fig. 3, Supplementary Material 3), with the caveat, however, that relatively few bathyal otolith assemblages are known from the late Oligocene and early Miocene. The morphological diversity of myctophids generally continued to increase, and during the early to early middle Miocene (Burdigalian to Langhian), the majority of extant genera came into existence (Fig. 2) (see also molecular phylogenetic estimates of Denton [2018]). The present highly diverse genus Diaphus, however, was represented by a relatively modest number of species in this interval (4 to 10 species per time interval), still displaying a relatively low level of morphological diversity. In mysticete cetaceans likewise, the disparity increased, and the first bulk filter feeders appeared (Marx and Fordyce 2015; Marx et al. 2016; Fordyce and Marx 2018). The body size of the mysticetes during that time interval barely reached $8 \mathrm{~m}$ in total length (Slater et al. 2017; Bianucci et al. 2019). The cause of this decrease in the size of lanternfishes (as exemplified by the most common genus Diaphus) and mysticete cetaceans and the associated reduction in diversity of diatoms is still not well understood. It may be related in some ways to a phase of global warming, that is, the late Oligocene warming (LOW) and the Miocene climate optimum (MCO) in the early Miocene (Burdigalian) and the early middle Miocene (Langhian). Cermeño et al. (2015) associated the observed decrease in diatom abundance and diversity with a reduced level of silica input in the Southern Ocean and a generally somewhat lowered silica influx in the global oceanic system.

The short period of the MMCT during the Serravallian marked the onset of a further 
stage of global cooling and change in deepocean circulation (Flower and Kennett 1994). Diatom diversity increased again (Lazarus et al. 2014), showing a distinct peak in abundance (Renaudie 2016). The continental denudation in response to the main phase of Alpine-Himalayan orogenesis (PeuckerEhrenbrink et al. 1995) and the global affirmation of phytolith-rich, grass-dominated ecosystems are regarded as the main drivers for the rising fluxes of silica responsible for the renewed diatom burst (Kidder and Gierlowski-Kordesch 2005; Edwards et al. 2010; Strömberg 2011; Cermeño et al. 2015). Both mysticete cetaceans (Bianucci et al. 2019) and myctophids, particularly of the genus Diaphus, show an increase in diversity and size (Fig. 3). Myctophid otoliths are firmly established as the dominant group in otolith assemblages from pelagic sediments (50\%-80\%; Fig. 3), for example, in the Mediterranean (Brzobohatý and Nolf 2000), tropical West Africa (Schwarzhans 2013c), and New Zealand (Schwarzhans 2019) (Supplementary Material 3).

Beginning with the late Miocene, the myctophid speciation rate continued to accelerate until today, which is consistent with the molecular estimation proposed by Denton (2018), particularly within the genus Diaphus (Fig. 3, Supplementary Material 2). Myctophid otoliths are the most common in all studied pelagic sediments, with percentages ranging between $40 \%$ and $95 \%$ of the specimens (Fig. 3, Supplementary Material 3). A dramatic increase occurred in the sizes of the otoliths in some lanternfishes, for example, certain species of the genera Diaphus, Lampadena, Myctophum, Notoscopelus, and Symbolophorus. Within the species-rich genus Diaphus, maximum otolith sizes increased from $6.7 \mathrm{~mm}$ OL in D. pedemontanus (Robba, 1970) in the Tortonian to $8.7 \mathrm{~mm}$ OL in D. coatesi Schwarzhans and Aguilera, 2013 in the Piacenzian and Gelasian, and eventually to $10.5 \mathrm{~mm}$ OL in the extant $D$. adenomus (Schwarzhans and Aguilera 2013) (Fig. 3, Supplementary Material 2). Late Miocene and younger pelagic sediments can often be readily recognized because of the abundance of large myctophid otoliths, always associated with a number of small-sized species as well. The late Miocene (Tortonian) to Recent interval was also characterized by mysticete gigantism (Bianucci et al. 2019) that culminated with the evolution of the extant blue whale, the largest animal that ever existed on Earth. Mysticete diversity was at its peak during the late Miocene and early Pliocene, followed by a drastic decrease since the late Pliocene (Marx and Fordyce 2015). The decrease of the diversity of mysticete cetaceans took place primarily at the expense of smaller species, while gigantism developed further. The gigantism has been interpreted as a reaction to the Arctic glaciation, changes in the distribution and availability of continental shelf habitats, and a greater need to migrate between high-latitude feeding and low-latitude breeding habitats (Berger 2007; Marx and Fordyce 2015). This is the only interval in the investigated time frame in which the evolution of lanternfishes (i.e., rapid diversification) diverged from that of mysticetes (i.e., diversity contraction). Diatom diversity and abundance increased during this time interval, though with a slight reduction during the Quaternary (Lazarus et al. 2014; Renaudie 2016). It is widely believed that the main driver of the diatom radiation and mysticete diversification and gigantism was the so-called biogenic bloom that occurred between 8 and $4 \mathrm{Ma}$ (Cortese et al. 2004; Filippelli 2008). We speculate that the biogenic bloom and its associated expansion of the oxygen minimum zones (see Dickens and Owen 1994) also represent the main trigger for the increase of diversity and size of the genus Diaphus. Two main mechanisms are currently considered as responsible for the biogenic bloom: an increased input of silica in the oceans caused by the uprising of $\mathrm{C}_{4}$-type grasslands on the continents (Kidder and Gierlowski-Kordesch 2005; Strömberg 2011) and their associated wildfire cycles (Beerling and Osborne 2006; Edwards et al. 2010; Pellegrino et al. 2018); and the massive erosion of the newly formed alpine mountain chains, especially the Himalayas, which released silica and phosphorus to the marine biosphere (Filippelli 2008; Cermeño et al. 2015). The initiation of the modern coastal upwelling systems during the late Miocene may have further contributed to the biogenic bloom (Berger 2007). The occurrence of supersized Diaphus species that started during the late Miocene (Messinian) 
and accelerated throughout the Pliocene up to today (Figs. 3, 4) can be tentatively related to the lifestyle of certain large-growing species that abandon diel vertical migration patterns and stay at depths between 300 and $1000 \mathrm{~m}$. The causes of this adaptation remain unknown, although they are likely related in some ways to the abundance of suitable larger, benthic prey. A similar cause may be evocated for the occasional occurrence of large-growing specimens of Lobianchia gemellarii (Cocco, 1838) that occur in expatriate flocks, that is, specimens occurring outside the usual distribution range of the species that do not reproduce because of the unfavorable conditions, mostly temperature related, but may continue to grow to very large sizes (see O'Day and Nafpaktitis 1967; Nafpaktitis 1968; Hulley 1984). Supersized L. gemellarii otoliths, presumably from expatriate flocks, have been observed in the Piacenzian and Gelasian of southern Japan (Schwarzhans and Ohe 2019).

\section{Conclusions and Outlook}

As described earlier, the evolution of lanternfishes as documented by their otoliths exhibits a remarkable parallelism with certain phases in the evolution of diatoms and mysticete cetaceans. We interpret this parallelism as an expression of an adaptive response of these organisms to large-scale changes of diverse nature that occurred in Earth's climate history, ocean configuration, and nutrient and silica supply. The abundance of diatoms has a shortening effect on the food chain and therewith a more effective nutrient transfer to higher trophic levels, which may have supported the evolution of bulk filter feeders such as mysticete cetaceans. We speculate that these oceanographic changes also promoted the migration of myctophids from the deep shelf to the mesopelagic zone of the open ocean, favoring their rise to dominance in the oceanic ecosystems. We recognize five phases in the evolutionary history of lanternfishes that are summarized in the following section.

Late Paleocene-Middle Eocene.-During the HTC ocean configuration, myctophid otoliths are generally rare (mostly $<25 \%$ of otolith assemblages) and occur from local inner-shelf positions to the outer shelf and possibly upper-slope environments. In the later part of the middle Eocene, they are locally abundant in certain outer-shelf positions, with up to $85 \%$ of otolith assemblages. Most likely, myctophids were not adapted to a mesopelagic life but had begun thriving over areas of the continental margins.

Late Eocene-Early Oligocene.-During the transformation of the deep-water circulation pattern and cooling in the oceans, we observe a remarkable increase in size of certain myctophids (Diaphus spp.), which parallels an acme in diatom diversity and abundance and a first occurrence of mysticete gigantism. Myctophid basal disparity (but not diversity) increased, as also suggested by molecular phylogenetic results (Denton 2018). Myctophids are found in deep-sea sediments for the first time in large quantities $(30 \%-55 \%)$, indicating their occupation of the mesopelagic zone. This radiation was probably triggered by the development of an early upwelling system and an increase in silica supply favoring the rise of diatoms and leading to a shortening of the trophic chain in the open ocean.

Late Oligocene-Early Middle Miocene.-This relatively warm climate phase (LOW and $\mathrm{MCO}$ ) is characterized by an increase in myctophid morphological diversity with the origin of the majority of the extant genera (consistent with the molecular temporal estimation proposed by Denton [2018]), associated however with a decrease in size. Myctophid otoliths are common in pelagic sediments and also occur regularly on the shelf.

Late Middle Miocene.-The Serravallian was characterized by a climate transition during the MMCT and also defines a transitional phase for myctophid evolution, with a further increase in diversity (since the Langhian) and a gradual increase of the maximum otolith size in Diaphus species. Lanternfishes are firmly established as the most common otoliths in pelagic sediments.

Late Miocene-Recent.-The sustained global cooling, onset of modern coastal upwelling systems, and intensification of silica supply from the continents likely triggered an increase of diatom diversity and abundance known as the biogenic bloom, as well as an abundance and diversity of lanternfishes $(50 \%-95 \%$ in 
pelagic sediments) and of mysticete cetaceans. The myctophid genus Diaphus is notable for an acceleration of the rate of speciation and a considerable increase of the maximum size of the otoliths during this time interval. This pattern parallels the rise of gigantic mysticetes, with the only significant difference being that myctophids showed a further acceleration in speciation during late Neogene (as also predicted by the molecular phylogenetic results; Denton 2018), while mysticetes exhibited a marked decrease in diversity from the late Pliocene to the Recent.

There are still many shortcomings in the knowledge of fossil myctophid otoliths despite the fact that a very significant increase in sampling from various world regions and stratigraphic intervals has been recently achieved. What appears to be the most severe shortcoming is the low number of otoliths sampled from Paleogene pelagic sediments, with only a few exceptions (Nolf and Steurbaut 1988, 1990, 2004; Schwarzhans 2019). Even Paleogene outer-shelf and upper-slope environments are underrepresented in otolith research (e.g., Brzobohatý 1967; Schwarzhans 1985; Nolf 1988; Brzobohatý and Nolf 1995, 1996; Lin et al. 2016). However, this time interval is important for a detailed unraveling of the early evolution of lanternfishes and their migration into the deep sea. Conversely, our knowledge of Neogene pelagic otolith assemblages is much more adequate, both from a stratigraphic and biogeographic point of view. In this case, additional knowledge could primarily be gained by the investigation of Neogene deposits from hitherto underrepresented regions of the world, for example, the areas bordering the Indian Ocean. Other highly promising and underrepresented regions for myctophid otolith research are the Neogene strata of Indonesia, New Guinea, the Philippines, and Pacific North America.

\section{Acknowledgments}

This study would have been impossible without the generous help of many colleagues making otolith collections available to W.S. or granting extraction of otoliths from voucher specimens. We wish to sincerely thank J. Paxton at
Australian Museum (Sydney), A. Suzimoto at Bernice P. Bishop Museum (Honolulu, Hawaii), H. Endo at Kochi University, Department of Biology (Kochi, Japan), D. Catania at California Academy of Sciences (San Francisco), R. Feeney at Los Angeles County Museum of Natural History (Los Angeles), K. Hartel and A. Williston at Museum of Comparative Zoology (Cambridge, Mass.), P. Bearez and G. Duhamel at Muséum National d'Histoire Naturelle (Paris), G. Shinohara at National Science Museum, Department of Zoology (Tsukuba, Tokyo), F. Ohe (Seto City, Japan), J. Williams and S. Raredon at National Museum of Natural History (Washington, D.C.), R. Thiel and A. Post at Universität Hamburg, Zoologisches Institut und Museum and former Institut für Seefischerei (Hamburg), and J. Nielsen and P. Møller at Københavns Universitet Zoologisk Museum (Copenhagen). P. Hulley (Cape Town) is cordially thanked for his very valuable and constructive discussion and advice with respect to extant myctophids. M. Bisconti (San Diego) and L. Pellegrino (Torino) are thanked for fruitful discussion and advice with respect to whale evolution and historical geology. The two anonymous reviewers and the associate editor $M$. Friedman are thanked for their constructive comments which helped to refine an earlier version of the article. The research of G.C. is supported by grants (ex-60\% 2020) from the Università degli Studi di Torino.

\section{Data Availability Statement}

Data available from the Dryad Digital Repository: https://doi.org/doi:10.5061/ dryad.cjsxksn54.

\section{Literature Cited}

Arambourg, C. 1927. Les poissons fossiles d'Oran. Matériaux pour la Carte Géologique de l'Algérie, $1^{\mathrm{er}}$ Série (Paléontologie) 6:1-218 Barker, P. F., G. M. Filippelli, F. Florindo, E. E. Martin, and H. D. Scher. 2007. Onset and role of the Antarctic Circumpolar Current. Deep-Sea Research II 54:2388-2398.

Bedini, E., P. Francalacci, and W. Landini. 1986. I pesci fossili del Miocene superiore di Montefiore Conca e Mondaino (Forlì) Memorie del Museo Civico di Storia Naturale di Verona 3:1-66.

Beerling, D. J., and C. P. Osborne. 2006. The origin of the savanna biome. Global Change Biology 12:2023-2031.

Beerling, D. J., and D. L. Royer. 2011. Convergent Cenozoic $\mathrm{CO}_{2}$ history. Nature Geoscience 4:418-420.

Berger, W. H. 2007. Cenozoic cooling, Antarctic nutrient pump, and the evolution of whales. Deep-Sea Research II 54:2399-2421. 
Bianucci, G., F. G. Marx, A. Collareta, A. Di Stefano, W. Landini, C. Morigi, and A. Varola. 2019. Rise of the titans: baleen whales became giants earlier than thought. Biology Letters 15:20190175.

Borrelli, C., B. S. Cramer, and M. E. Katz. 2014. Bipolar Atlantic deepwater circulation in the middle-late Eocene: effects of Southern Ocean opening. Paleoceanography 29:308-327.

Briggs, D. E. G., M. J. Weedon, and M. A. Whyte. 1993. Crustacea, excluding Ostracoda. Pp. 321-342 in: M.J. Benton, ed. The fossil record 2. Chapman and Hall, London.

Brzobohatý, R. 1967. Die Fisch-Otolithen aus den PouzdranySchichten. Acta Musei Moraviae, Scientiae Naturalis 52:121-168.

Brzobohatý, R., and D. Nolf. 1995. Diaphus otoliths from the European Oligocene (Myctophidae, Teleostei). Bulletin de l'Institute Royal des Sciences Naturelles de Belgique, Sciences de la Terre 65:257-268.

Brzobohatý, R., and D. Nolf. 1996. Otolithes de myctophidés (poissons téléostéens) des terrains teriaires d'Europe: révision des genres Benthosema, Hygophum, Lampadena, Notoscopelus et Symbolophorus. Bulletin de l'Institute Royal des Sciences Naturelles de Belgique, Sciences de la Terre 66:151-176.

Brzobohatý, R., and D. Nolf. 2000. Diaphus otoliths from the European Neogene (Myctophidae, Teleostei). Bulletin de l'Institute Royal des Sciences Naturelles de Belgique, Sciences de la Terre 70:185-206.

Buono, M. R., R. E. Fordyce, F. G. Marx, M. S. Fernández, and M. A. Reguero. 2019. Eocene Antarctica: a window into the earliest history of modern whales. Advances in Polar Science 30. doi:10.13679/j.advps.2019.0005.

Carnevale, G. 2007. Fossil fishes from the Serravallian (Middle Miocene) of Torricella Peligna, Italy. Palaeontographia Italica 91:1-67.

Catul, V., M. Gauns, and P. K. Karuppasamy. 2011. A review on mesopelagic fishes belonging to family Myctophidae. Reviews of Fish Biology and Fisheries 21:339-354.

Cermeño, P., P. G. Falkowski, O. E. Romero, M. F. Schaller, and S. M. Vallina. 2015. Continental erosion and the Cenozoic rise of marine diatoms. Proceedings of the National Academy of Sciences USA 112:4239-4244.

Cione, A. L., and M. A. Reguero. 1998. A middle Eocene basking shark (Lamniformes, Cetorhinidae) from Antarctica. Antarctic Science 10:83-88.

Coccioni, R., and S. Galeotti. 2003. Deep-water benthic foraminiferal events from the Massignano Eocene/Oligocene boundary stratotype, Central Italy. Pp. 438-453 in D. R. Prothero, L. C. Ivany, and E. A. Nesbitt, eds. From greenhouse to icehouse: the marine Eocene-Oligocene transition. Columbia University Press, New York

Cocco, A. 1838. Su di alcuni salmonidi del mare di Messina. Nuovi annali delle scienze naturali e rendiconto dei lavori dell'Accademia della Scienze dell'Instituto di Bologna con appendice agraria Bologna Anno 1 Tomo 2 (fasc. 9):161-194.

Cortese, G., R. Gersonde, C.-D. Hillenbrand, and G. Kuhn. 2004. Opal sedimentation shifts in the World Ocean over the last 15 Myr. Earth and Planetary Science Letters 224:509-527.

Coxall, H. K., C. E. Huck, M. Huber, C. H. Lear, A. Legarda-Lisarri, M. O'Regan, K. K. Sliwinska, T. van de Flierdt, A. M. de Boer, J. C. Zachos, and J. Backman. 2018. Export of nutrient rich northern component water preceded early Oligocene Antarctic glaciation. Nature Geoscience 11:190-196.

David, L. R. 1943. Miocene fishes of Southern California. Geological Society of America Special Paper 43:1-193.

Denton, J. J. S. 2013. Lanternfish (Teleostei, Myctophiformes, Myctophidae) body fossils from the Modelo Formation (upper Miocene) of Los Angeles County, California. Journal of Vertebrate Paleontology 33:786-793.

Denton, J. S. S. 2018. Diversification patterns of lanternfishes reveal multiple rate shifts in a critical mesopelagic clade targeted for human exploitation. Current Biology 28:933-940.
Dickens, G. R., and R. M. Owen. 1994. Late Miocene-early Pliocene manganese redirection in the central Indian Ocean: expansion of the intermediate water oxygen minimum zone. Paleoceanography 9:169-181.

Dietze, K. 2009. Morphology and phylogenetic relationships of certain neoteleostean fishes from the Upper Cretaceous of Sendenhorst, Germany. Cretaceous Research 30:559-574.

Douglas, E. L., W. A. Friedl, and G. V. Pickwell. 1976. Fishes in oxygen-minimum zones: blood oxygenation characteristics. Science 1991:957-959.

Edwards, E. J., C. P. Osborne, C. A. E. Strömberg, S. A. Smith, and $\mathrm{C}_{4}$ Grasses Consortium. 2010. The origins of $\mathrm{C}_{4}$ Grasslands: integrating evolutionary and ecosystem science. Science 328:587-591.

Filippelli, G. M. 2008. The global phosphorus cycle: past, present, and future. Elements 4:89-95.

Flower, B. P., and J. P. Kennett. 1994. The middle Miocene climatic transition: East Antarctic ice sheet development, deep ocean circulation and global carbon cycling. Palaeogeography, Palaeoclimatology, Palaeoecology 108:537-555.

Fordyce, R. E. 2003. Cetacean evolution and Eocene-Oligocene oceans revisited. Pp. 154-170 in D. R. Prothero, L. C. Ivany, and E. A. Nesbitt, eds. From greenhouse to icehouse: the marine Eocene-Oligocene transition. Columbia University Press, New York.

Fordyce, R. E., and L. G. Barnes. 1994. The evolutionary history of whales and dolphins. Annual Review of Earth and Planetary Sciences 22:419-455.

Fordyce, R. E., and F. G. Marx. 2018. Gigantism precedes filter feeding in baleen whale evolution. Current Biology 28:1-7.

Freer, J. J. 2018. Ecological niches and geographic distributions of lanternfishes. Ph.D. thesis. University of Bristol, Bristol, U.K. P. 233.

Froese, R., and D. Pauly, eds. 2020. FishBase. Version 12/2019. http://www.fishbase.se/search.php, accessed July 2020.

Gilbert, C. H. 1905. The deep-sea fishes of the Hawaiian Islands. In The aquatic resources of the Hawaiian Islands. Bulletin of the U. S. Fish Commission 23:577-713

Gjøsaeter, J. 1984. Mesopelagic fish, a large potential resource in the Arabian Sea. Deep-Sea Research 31:1019-1035.

Gjøsaeter, J., and K. Kawaguchi. 1980. A review of the world resources of mesopelagic fish. FAO Fisheries Technical Paper 193:1-151.

Goldner, A., N. Herold, and M. Huber. 2014. Antarctic glaciation caused ocean circulation changes at the Eocene-Oligocene transition. Nature 511:574-577.

Gong, Y., Y. Yang, X. Kong, J. Zhang, Y. Jiang, Z. Chen, L. Yan, and K. Zhang. 2018. A preliminary study on the fishery-relevant biology of Diaphus watasei in the continental slope of the northern South China Sea. Journal of Fishery Sciences of China 25:10911101. [In Chinese with English summary.]

Goody, P. C. 1969. The relationships of certain Upper Cretaceous teleosts with special reference to myctophiforms. Bulletin of the British Museum (Natural History) Geology Supplement 7:1-255.

Gregorová, R. 2004. A new Oligocene genus of lanternfish (family Myctophidae) from the Carpathian Mountains. Revue de Paléobiologie 9:81-97.

Houben, A. J. P., P. K. Bijl, J. Pross, S. M. Bohaty, S. Passcjier, C. E. Stickley, U. Röhl, S. Sugisaki, L. Tauxe, T. van de Flierdt, M. Olney, F. Sangiorgi, A. Sluijs, C. Escutia, and H. Brinkhuis. 2013. Reorganization of Southern Ocean plankton ecosystem at the onset of Antarctic glaciation. Science 340:341-344.

Hulley, P. A. 1981. Results of the research cruises of FRV "Walter Herwig" to South America. LVIII. Family Myctophidae (Osteichthyes, Myctophiformes). Archiv für Fischereiwissenschaft 31 (1):1-300.

Hulley, P. A. 1984. Myctophidae. Pp. 429-483 in P. J. P. Whitehead, M.-L. Bauchot, J.-C. Hureau, J. Nielsen, and E. Tortonese, eds. 
Fishes of the north-eastern Atlantic and the Mediterranean. UNESCO, Paris.

Hulley, P. A. 1992. Upper-slope distributions of oceanic lanternfishes (family: Mactophidae). Marine Biology 114:365-383.

Hulley, P. A., and J. R. E. Lutjeharms. 1989- Lanternfishes of the southern Benguela region. Part 3. The pseudoceanic-oceanic interface. Annales of the South African Museum 98:409-435.

Irigoien, X., T. A. Klevjer, A. Røstad, U. Martinez, G. Boyra, J. L. Acuña, A. Bode, F. Echevarria, J. I. GonzalezGordillo, S. Hernandez-Leon, S. Agusti, D. L. Aksnes, C. M. Duarte, and S. Kaartvedt. 2014. Large mesopelagic fishes biomass and trophic efficiency in the open ocean. Nature Communications 4271:1-10.

Jovane, L., R. Coccioni, A. Marsili, and G. Acton. 2009. The late Eocene greenhouse-icehouse transition: observations from the Massignano global stratotype section and point (GSSP). In C. Koeberl and A. Montanari, eds. The late Eocene Earth-hothouse, icehouse, and impacts. Geological Society of America Special Paper 452:149-168.

Kaardtveldt, S., A. Staby and D. L. Aksnes. 2012. Efficient trawl avoidance by mesopelagic fishes causes large underestimation of their biomass. Marine Ecology Progress Series 456:1-6.

Kalabis, V. 1948. Ryby se světelnými orgány z moravského palégenu. Časopis Moravského Muzea 32:131-234. [In Czech.]

Katz, M. E., B. S. Cramer, J. R. Toggweiler, G. Esmay, C. Liu, K. G. Miller, Y. Rosenthal, B. S. Wade, and J. D. Wright. 2011. Impact of Antarctic circumpolar current development on late Paleogene ocean structure. Science 332:1076-1079.

Kawamura, A. 1980. A review of food of balaenopterid whales. Scientific Reports the Whales Research Institute 32:155-197.

Kennett, J. P. 1977. Cenozoic evolution of Antarctic glaciation, the Circum-Antarctic Ocean, and their impact on global paleoceanography. Journal of Geophysical Research 82:3843-3860.

Kennett, J. P., and N. F. Exon. 2004. Paleoceanographic evolution of the Tasmanian Seaway and its climatic implications. Geophysical Monograph Series 151:345-367.

Kidder D. I., and E. H. Gierlowski-Kordesch. 2005. Impact of grassland radiation on the nonmarine silica cycle and Miocene diatomite. Palaios 20:198-206.

Koken, E. 1884. Über Fisch-Otolithen, insbesondere über diejenigen der norddeutschen Oligocän-Ablagerungen. Zeitschrift der Deutschen Geologischen Gesellschaft 36:500-565.

Lam, V. W. Y., and D. Pauly. 2005. Mapping the global biomass of mesopelagic fishes. Sea Around Us, July/August, p. 4.

Lazarus, D., J. Barron, J. Renaudie, P. Diver, and A. Türke. 2014. Cenozoic planktonic marine diatome diversity and correlation to climate change. PLoS ONE 9:e84857.

Lear, C. H., Y. Rosenthal, H. K. Coxall, and P. A. Wilson. 2004. Late Eocene to early Miocene ice sheet dynamics and the global carbon cycle. Paleoceanography 19:PA4015:1-11.

Lin, C.-H., D. Nolf, E. Steurbaut, and A. Girone. 2016. Fish otoliths from the Lutetian of the Aquitaine Basin (SW France), a breakthrough in the knowledge of the European Eocene ichthyofauna. Journal of Systematic Palaeontology 15:879-907.

Lowery, C. M., P. R. Bown, A. J. Fraass, and P. M. Hull. 2020. Ecological response of plankton to environmental change: thresholds for extinction. Annual Review of Earth and Planetary Sciences 48:16.1-16.27.

Marshall, N. B. 1979. Developments in deep-sea biology. Blandford Press, Poole, U.K. P. 566.

Martin, R. P., E. E. Olson, M. G. Girard, W. L. Smith, and M. P. Davis. 2018. Light in the darkness: new perspective on lanternfish relationships and classification using genomic and morphological data. Molecular Phylogenetics and Evolution 121:71-85.

Marx, F. G., and R. E. Fordyce. 2015. Baleen boom and bust: a synthesis of mysticete phylogeny, diversity and disparity. Royal Society Open Science 2:140434:1-14
Marx, F. G., and M. D. Uhen. 2010. Climate, critters, and Cetaceans: Cenozoic drivers of the evolution of modern whales. Science 327:993-996.

Marx, F. G., O. Lambert, and M. D. Uhen. 2016. Cetacean Paleobiology. P. 319 in Topics in paleobiology. Wiley Blackwell, Chichester, U.K.

Marx, F. G., M. R. Buono, A. R. Evans, R. E. Fordyce, M. Reguero, and D. P. Hocking. 2019. Gigantic mysticete predators roamed the Eocene Southern Ocean. Antarctic Science 31:98-104.

McClain, C. R., and S. M. Hardy. 2010. The dynamics of biogeographic ranges in the deep sea. Proceedings of the Royal Society of London B 277:3533-3546.

Meera, K. M., M. Hashim, V. N. Sanjeevan, J. Jayasankar, T. V. Ambrose, and M. Sudhakar. 2018. Systematics and biology of the blue lanternfish, Diaphus coeruleus from the south-eastern Arabian Sea. Journal of the Marine Biological Association of the United Kingdom 99:239-248.

Miller K. G., M. E. Katz, and W. A. Berggren. 1992. Cenozoic deepsea benthic foraminifera: a tale of three turnovers. Pp. 67-75 in Studies in benthic foraminifera, BENTHOS' 90, Sendai. Tokai University Press, Kanakawa, Japan.

Muizon, C. de, G. Bianucci, M. Martínez-Cáceres, and O. Lambert. 2019. Mystacodon selenensis, the earliest known toothed mysticete (Cetacea, Mammalia) from the late Eocene of Peru: anatomy, phylogeny, and feeding adaptations. Geodiversitas 41:401-499.

Nafpaktitis, B. 1968. Taxonomy and distribution of the lanternfishes, genera Lobianchia and Diaphus, in the North Atlantic. Dana-Report 73:1-131.

Nolf, D. 1985. Otolithi Piscium. P. 145 in Handbook of paleoichthyology, Vol. 10. Gustav Fischer Verlag, Stuttgart.

Nolf, D. 1988. Les otolithes de téléostéens éocènes d'Aquitaine (sud-ouest de la France) et leur intérêt stratigraphique. Mémoire de l'Académie Royale de Belgique 19:1-147.

Nolf, D. 2013. The diversity of fish otoliths, past and present. Royal Belgian Institute of Natural Sciences, Brussels. P. 222.

Nolf, D., and R. Brzobohatý. 2002. Otolithes de poissons du paléocanyon de Saubrigues (Chattian à Langhian), Aquitaine Méridionale, France. Revue de Micropaléontologie 45:261-296.

Nolf, D., and E. Steurbaut. 1988. Description de la première faune ichthyologique exclusivement bathyale du Tertiare d'Europe: otolithes de l'Oligocène Inférieur du gisement de Pizzocorno, Italie septentrionale. Bulletin de l'Institut Royal des Sciences Naturelles de Belgique 57:217-230.

Nolf, D., and E. Steurbaut. 1990. Découverte de poissons bathyaux d'âge Oligocène inférieur à Pizzocorno, près de Voghera. Quaderni della sezione di Scienze Naturali del Civico Museo di Voghera 10:15-31.

Nolf, D., and E. Steurbaut. 2004 .Otolithes de poissons de l'Oligocène inférieur du Basssin liguro-piémontais oriental, Italie. Rivista Piemontese di Storia naturale 25:21-68.

Norris, R. D., S. K. Turner, P. M. Hull, and A. Ridgwell. 2013. Marine ecosystem responses to Cenozoic global change. Science 341:492-498.

O'Day, W. T., and B. Nafpaktitis. 1967. A study of the effects of expatriation on the gonads of two myctophid fishes in the North Atlantic Ocean. Bulletin of the Museum of Comparative Zoology 136:77-90.

Patterson, C. 1993. Osteichthyes: Teleostei. Pp.621-656 in M J. Benton, ed. The fossil record 2. Chapman and Hall, London.

Pauca, M. 1931. Zwei Fischfaunen aus den Oligozänen Menelitschiefern von Mähren. Annalen des Naturhistorischen Museums in Wien 46:147-152.

Paxton, J. R. 1972. Osteology and relationships of the lanternfishes (family Myctophidae). Bulletin of the Natural History Museum of Los Angeles County, Science 13:1-81.

Pellegrino, L., F. Dela Pierre, M. Natalicchio, and G. Carnevale. 2018. The Messinian diatomite deposition in the Mediterranean 
region and its relationships to the global silica cycle. Earth-Science Reviews 178:154-176.

Peucker-Ehrenbrink, B., G. Ravizza, and A. W. Hofmann. 1995. The marine ${ }^{187} \mathrm{Os} /{ }^{186} \mathrm{Os}$ record of the past 80 million years. Earth and Planetary Science Letters 130:155-167.

Popper, A. N. 1977. Scanning electron-microscopic study of sacculus and lagena in ears of 15 species of teleost fishes. Journal of Morphology 153:397-417.

Přikryl, T., W. Schwarzhans, and O. Kovalchuk. 2017. Lanternfishes (Myctophidae) with otoliths in situ from the Early Oligocene of the Eastern Paratethys (western Ukraine). Neues Jahrbuch Geologie und Paläontologie Abhandlungen 285:213-225.

Prokofiev, A. M. 2006. Fossil myctophid fishes (Myctophiformes: Myctophoidei) from Russia and adjacent regions. Journal of Ichthyology 46:38-83.

Rathnasuriya, M. I. G., H. A. C. C. Perera, and R. P. P. K. Jayasinghe. 2018. Feeding ecology of the headlight fish Diaphus effulgens (Actinopterygii, Myctophidae) in the Bay of Bengal. P. 23 in Proceedings of the Twenty-Fourth Scientific Sessions of the Sri Lanka Association for Fisheries and Aquatic Resources, 8th June 2018. University of Kelaniya Dalugama, Sri Lanka.

Renaudie, J. 2016. Quantifying the Cenozoicmarine diatom deposition history: links to the $C$ and Si cycles. Biogeosciences 13:6003-6014.

Rigby, S., and C. V. Milsom. 2000. Origins, evolution and diversification of zooplankton. Annual Review of Ecology and Systematics 31:293-313.

Rivaton, J., and P. Bourret. 1999. Les otolithes des poissons de l'Indo-Pacificque. P. 378 in Documents scientifiques et techniques, Centre IRD de Nouméa, II2, volume spécial. Institute de recherche pour le développement, Centre de Nouméa, New Caledonia.

Robba, E. 1970. Otoliti del Tortoniano-tipo (Piemonte). Rivista Italiana di Paleontologia 76:89-172.

Robison, B. H., R. E. Sherlock, K. R. Reisenbichler, and P. R. McGill. 2020. Running the gauntlet: assessing the threats to vertical migrators. Frontiers in Marine Science 7:ar64.

Ryther, J. H. 1969. Photosynthesis and fish production in the sea. Science 166:72-76.

Sato, J. 1962. Miocene fishes from the western area of Shizukuishi Basin, Iwate Prefecture, northeastern Japan. Earth Science (Chikyu Kagaku) 59:1-29.

Sato, J. 1965. Myctophid fish from the Ashikawa Formation, southern Fossa Magna, Japan. Earth Science 81:17-20.

Scher, H. D., and E. E. Martin. 2006. Timing and climatic consequences of the opening of Drake Passage. Science 312:428-430.

Schwarzhans, W. 1978. Otolith-morphology and its usage for higher systematical units with special reference to the Myctophiformes s.l. Mededelingen van de Werkgroep voor Tertiaire en Kwartaire Geologie 15:167-185.

Schwarzhans, W. 1985. Tertiäre Otolithen aus South Australia und Victoria (Australien). Palaeo Ichthyologica 3:1-60.

Schwarzhans, W. 2010a. Otolithen aus den Gerhartsreiter Schichten (Oberkreide: Maastricht) des Gerhartsreiter Grabens (Oberbayern). Palaeo Ichthyologica 4:1-100.

Schwarzhans, W. 2010b. The otoliths from the Miocene of the North Sea Basin. Backhuys, Leiden; Margraf, Weikersheim. P. 352.

Schwarzhans, W. 2012. Fish otoliths from the Paleocene of Bavaria (Kressenberg) and Austria (Kroisbach and Oiching-Graben). Palaeo Ichthyologica 12:1-88.

Schwarzhans, W. 2013a. Otoliths from dredges in the Gulf of Guinea and off the Azores - an actuo-paleontological case study. Palaeo Ichthyologica 13:7-40.

Schwarzhans, W. 2013b. A comparative morphological study of the Recent otoliths of the genera Diaphus, Idiolychnus and Lobianchia (Myctophidae). Palaeo Ichthyologica 13:41-82.

Schwarzhans, W. 2013c. Otoliths from the Miocene of West Africa, primarily from the Mandorové Formation of Gabon. Palaeo Ichthyologica 13:151-184.
Schwarzhans, W. 2019. Reconstruction of the fossil marine fish fauna (Teleostei) from the Eocene to Pleistocene of New Zealand by means of otoliths. Memorie della Società Italiana di Scienze Naturali e del Museo di Storia Naturale di Milano 46:3-326.

Schwarzhans, W., and O. Aguilera. 2013. Otoliths of the Myctophidae from the Neogene of tropical America. Palaeo Ichthyologica 13:83-150.

Schwarzhans, W., and F. Ohe. 2019. Lanternfish otoliths (Teleostei, Myctophidae) from the Pliocene and Pleistocene of Japan. Rivista Italiana di Paleontologia e Stratigrafia 125:355-400.

Schwarzhans, W., T. Mörs, A. Engelbrecht, M. Reguero, and J. Kriwet. 2017. Before the freeze: otoliths from the Eocene of Seymour Island, Antarctica, reveal dominance of gadiform fishes (Teleostei). Journal of Systematic Palaeontology 15:147-170.

Sibert, E. C., M. E. Zill, E. T. Frigyik, and R. D. Norris. 2020. No state change in pelagic fish production and biodiversity during the Eocene-Oligocene transition. Nature Geoscience 13:238-242.

Slater, G. J., J. A. Goldbogen, and N. D. Pyenson. 2017. Independent evolution of baleen whale gigantism linked to Plio-Pleistocene ocean dynamics. Proceedings of the Royal Society of London B 284:20170546:1-8.

Sommer, U., H. Stibor, A. Katechakis, F. Sommer, and T. Hansen. 2002. Pelagic food web configurations at different levels of nutrient richness and their implications for the ratio fish production: primary production. Hydrobiologia 484:11-20.

Steeman, M. E., M. B. Hebsgaard, R. E. Fordyce, S. Y. W. Ho, D. L. Rabosky, R. Nielsen, C. Rahbek, H. Glenner, M. V. Sørensen, and E. Willerslev. 2009. Radiation of extant Cetaceans driven by restructuring of the oceans. Systematic Biology 58:573-585.

Steurbaut, E. 1979. Les otolithes de Téléostéens des Marnes de Saubrigues (Miocéne d'Aquitaine méridionale, France). Palaeontographica, A 166:50-91.

Strömberg, C. A. E. 2011. Evolution of grasses and grassland ecosystems. Annual Review of Earth and Planetary Sciences 39:517-544.

Strugnell, J. M., A. D. Rogers, P. A. Prodöhl, M. A. Collins, and A. L. Allcock. 2008. The thermohaline expressway: the Southern Ocean as a centre of origin for deep-sea octopuses. Cladistics 24:853-860.

Tanaka, H., S. Ohshimo, C. Sassa, and I. Aoki. 2007. Feeding habits of mesopelagic fishes off the coast of western Kyushu, Japan. Pices 16th: BIO_P-4200.

Thomas, E. 2007. Cenozoic mass extinctions in the deep sea: What perturbs the largest habitat on Earth? In S. Monechi, R. Coccioni, and M. R. Rampino, eds. Large ecosystem perturbations: causes and consequences. Geological Society of America Special Paper 424:1-23.

Tuset, V. M., M. P. Olivar, J. L. Otero-Ferrer, C. López-Pérez, P. A. Hulley, and A. Lombarte. 2018. Morpho-functional diversity in Diaphus spp. (Pisces: Myctophidae) from the central Atlantic Ocean: ecological and evolutionary implications. Deep-Sea Research, part I (Oceanographic Research Papers) 138:46-59.

Uyeno, T., and N. Matsui. 1993. Late Cretaceous fish fossils from Nemuro, Hokkaido, Japan. Memoirs of the National Science Museum, Tokyo 26:39-46. [In Japanese.]

van Tuyll, C. I., R. S. W. van de Wal, and J. Oerlemans. 2007. The response of a simple Antarctic ice-flow model to temperature and sea-level fluctuations over the Cenozoic era. Annals of Glaciology 46:69-77.

Watanabe, H., M. Moku, K. Kawaguchi, K Ishimaru, and A. Ohno. 1999. Diel vertical migration of myctophid fishes (family Myctophidae) in the transitional waters of the western North Pacific. Fisheries Oceanography 8:115-127.

Weiler, W. 1942. Die Otolithen des rheinischen und nordwestdeutschen Tertiärs. Abhndlungen des Reichsamts für Bodenforschung, Neue Folge 206:1-140.

Welton, B. J. 2013. A new archaic basking shark (Lamniformes: Cetorhinidae) from the late Eocene of western Oregon, U.S.A., 
and description of the dentition, gill rakers and vertebrae of the recent basking shark Cetorhinus maximus (Gunnerus). New Mexico Museum of Natural History and Science Bulletin 58:1-48.

Yabumoto, Y., and T. Uyeno. 1994. Late Mesozoic and Cenozoic fish faunas of Japan. The Island Arc 3:255-269.

Zachos, J. C., G. R. Dickens, and R. E. Zeebe. 2008. An early Cenozoic perspective on greenhouse warming and carbon-cycle dynamics. Nature 451:279-283.
Zhang, Z., K. H. Nisancioglu, F. Flatøy, M. Bentsen, I. Bethke, and H. Wang. 2011. Tropical seaways played a more important role than high latitude seaways in Cenozoic cooling. Climate of the Past Discussions 7:965-996.

Zorzin, R., A. F. Bannikov, E. Fornaciari, L. Giusberti, C. A. Papazzoni, and G. Roghi. 2011. Il giacimento a pesci e piante fossili dell'Eocene inferiore di Monte Solane (Verona). Bollettino del Museo Civico di Storia Naturale di Verona 35:57-64. 